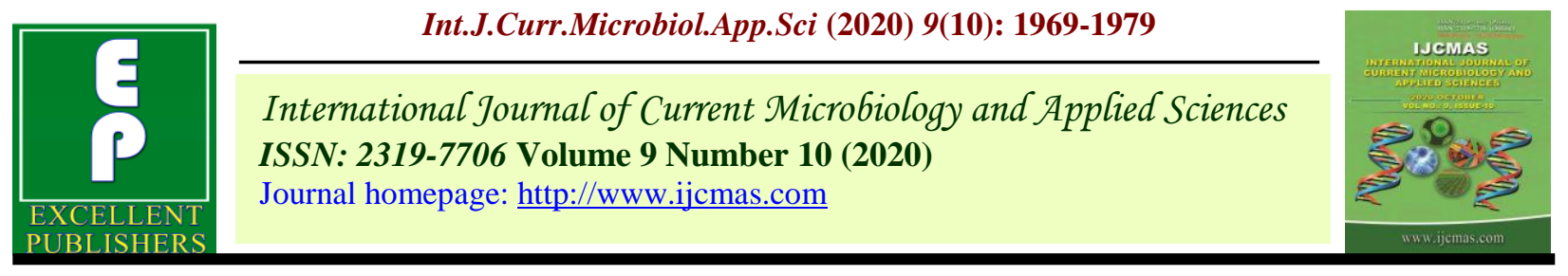

Original Research Article

https://doi.org/10.20546/ijcmas.2020.910.240

\title{
Impact of Water Cooking on Nutritive Characteristics of Justicia galeopsis Leaves Consumed in Côte d'Ivoire
}

\author{
Ahou Leticia Loukou*, Raissa Sandy Assi, Koutoua Yves Blanchard Anvoh, \\ Kouakou Brou and Louise Atchibri-Anin
}

\author{
Food Science and Technology Department, Nangui Abrogoua University, \\ Abidjan 02 BP 801, Abidjan 02, Côte d'Ivoire
}

*Corresponding author

\begin{abstract}
A B S T R A C T
\section{Keywords}

Justicia galeopsis leaves, Water cooking, Nutritional composition, Antinutritional factors, Mineral bioavailability

Article Info

Accepted: 15 September 2020 Available Online: 10 October 2020

This study aimed at determining the effect of cooking time on nutritive characteristics of Justicia galeopsis leaves. J. galeopsis leaves were collected from cultivated farmlands located at Abobo and boiled at $100{ }^{\circ} \mathrm{C}$ respectively during 30, 45 and $60 \mathrm{~min}$. Then, nutrients and antinutrients compositions were investigated using standard methods. Some molar ratios between antinutrients and mineral were also calculated and mineral bioavailability predicted. The results revealed that longer time of cooking (higher than 30 min) led to 5-14 \% drop in protein level, 21-36 \% in ash, 95-97\% in Vitamin C, 4-42 \% in polyphenol, $19-63 \%$ in flavonoids, $18-59 \%$ in tannin, $10-46 \%$ in oxalate and $12-34 \%$ reduction in phytate content in J. galeopsis leaves. However, cooking improved lipids contents to $12-13 \%$, carbohydrate $6-11 \%$, fiber $13-44 \%$, and the mineral bioavailability with iron, zinc, calcium and magnesium. Further more, J. galeopsis leaves boiled during $30 \mathrm{~min}$ had the highest residual contents in proteins $(13,33 \%)$, lipids $(2.24 \%)$, ashes $(12.33 \%)$, carbohydrates $(72.09 \%)$, phosphorus $(16.83 \mathrm{~g} / \mathrm{kg})$, potassium $(314.75 \mathrm{~g} / \mathrm{kg})$, calcium (30.66 g/kg), magnesium $(5.20 \mathrm{~g} / \mathrm{kg})$, sodium $(10.58 \mathrm{mg} / \mathrm{kg})$, iron $(458.98 \mathrm{mg} / \mathrm{kg})$, polyphénols (79.91 mg EAG/100 g), flavonoïds13.39 mg EQ/100 g), tannins (54.44 mg EC/100 g). The recommended cooking time of J. galeopsis leaves must be less than 30 min in order to contribute efficiently to the recovery of anemic patients and the food security of Ivorian population.
\end{abstract}

\section{Introduction}

The interest in plant foods has increased following epidemiological studies relating eating habits and the prevalence of certain diseases (cancers, obesity, cardiovascular diseases). Salkeld (1991) reports that, according to epidemiologists, 25 to $60 \%$ of cancers could be prevented by modifying eating habits. The main nutritional interest of vegetables lies in their supply of minerals, vitamins and dietary fiber. Leafy vegetables constitute essential components of human diet in Africa generally and particularly in West Africa (Kubmarawa et al., 2009). They provide more minerals than other vegetables. Their daily consumption allows a satisfactory dietary balance. In addition to their nutritional 
importance, leafy vegetables are considerable economic and social interest because of their relatively low cost and the ease and speed of their preparation (Gupta and Wagle, 1988).

Justicia galeopsis T. Anderson ex C.B. Clarke belongs to leafy vegetables family. It has been discovered in Côte d'Ivoire by Yao et al (2014). The Justicia galeopsis leaves are known for mainly its medicinal purpose and its high amount of total phenolics. In Abengougou Division, all the population has already consumed the leaves of this plant (Loukou et al., 2018).

According to Loukou et al. (2018), J. galeopsis fresh leaves are very nutritive. They could help cover people's nutritional needs and contribute to food security. These leaves were very rich in fiber $(33.85 \%)$, protein $(21.11 \%)$, vitamin B12 (4173.09 mg/kg) and vitamin C $(892.17 \mathrm{mg} / \mathrm{kg}$ of fresh leaf) but low in fat $(4.06 \%)$. The mineral elements contents were high $(17.76 \%)$ with remarkable amount of potassium $(103.08 \mathrm{~g} / \mathrm{kg})$, phosphorus $(77.66 \mathrm{~g} / \mathrm{kg})$, calcium $(59.87$ $\mathrm{g} / \mathrm{kg})$, sodium $(28.30 \mathrm{~g} / \mathrm{kg})$, iron $(373.01$ $\mathrm{mg} / \mathrm{kg})$, zinc $(177.84 \mathrm{mg} / \mathrm{kg})$ and manganese $(128.57 \mathrm{mg} / \mathrm{kg})$. Despite the presence of phytate $(33.83 \mathrm{mg} / 100 \mathrm{~g})$, oxalate $(740.67$ $\mathrm{mg} / 100 \mathrm{~g}$ ) and tannin $(66.33 \mathrm{mg} / 100 \mathrm{~g})$, the calcium, zinc, iron and magnesium in this plant have a high bioavailability.

In Côte d'Ivoire, more than twenty (20) species of leafy vegetables like Justicia galeopsis leaves are consumed by populations through confectionary soups using boiling or blanched processing (CNRA, 2011) like Justicia galeopsis leaves. Cooking vegetables improves digestibility by changing the structure of dietary fiber. However, it also causes a more or less marked decrease in the nutritional value, either by defusing watersoluble constituents in the cooking water, or by destruction of thermolabile and / or oxidizable substances. Losses are generally higher for leafy vegetables than for roots and tubers. They increase with the volume of water used and the duration of cooking (Causeret, 1986).

Several works and reports have revealed that cooking or preparation methods and period of cooking may affect the nutritional value as well as the bioavailability of many nutrients in leafy vegetables (Gupta and Bains, 2006; Leskova et al., 2006). However, the literature does not mention nutritional value of cooked leaves of Justicia galeopsis leaves.

The aim of this work was to assess the effect of cooking on the physicochemical and nutritive properties of Justicia galeopsis leaves in order to as certain its nutritional suitability as well as health benefits.

\section{Materials and Methods}

\section{Sampling}

Justicia galeopsis leaves, commonly known in the local language "Agni" as Assiaploua were collected fresh and at maturity from cultivated farmlands located at Abobo. Abobo is one of thirteen communes of the district of Abidjan, Côte d'Ivoire. It is located in Abidjan north between $5^{\circ} 42$ north latitude and $-4^{\circ} 02$ west longitude and at an altitude of105 meters above sea level (Aka et al., 2013). Plants were identified and authenticated by National Floristic Center (University Felix Houphouët Boigny, Abidjan-Côte d'Ivoire).

\section{Samples processing}

The fresh leaves were destalked, washed with distilled water, drained at ambient temperature. Collected leaves were divides into four lots. The first lot is that of the fresh leaves. An amount of fresh leaves was mixed 
with water in the proportion described by Agbemafle et al. (2012) such $40 \mathrm{~g}$ of leafy vegetables for $200 \mathrm{~mL}$ of water. Then, the mixture was lyophilized. The other three lots were cooked at $100{ }^{\circ} \mathrm{C}$ respectively during 30, 45 and $60 \mathrm{~min}$ by using the method of Randrianatoandro (2010) in the proportion 40 $\mathrm{g}$ of leafy vegetables immerged in $200 \mathrm{~mL}$ of boiled water. Boiled samples were cooled, ground with a laboratory crusher (Culatti, France) and also lyophilized. All lyophilized samples were ground again in fine powder and store in a clean dry air-tight bottle in a refrigerator $\left(4^{\circ} \mathrm{C}\right)$ until required for analyses.

\section{Nutritive characterization}

\section{Proximate composition analysis}

Moisture, ash, proteins, and lipids were determined by AOAC method (AOAC, 1990). Total fiber content was determined using Weende method (Wolf, 1968). The amount of carbohydrates was determined by difference using FAO method (FAO, 1998) as follows:

$\%$ Carbohydrates $=100-(\%$ moisture $+\%$ proteins $+\%$ lipids $+\%$ ash). Total sugar was determined by Dubois et al. (1956). The amount of reducing sugars was estimated by the method of Bernfeld (1955).

\section{Minerals and Vitamin $\mathrm{C}$ determination}

Mineral content was estimated by dry ashing of dried powdered sample $(5 \mathrm{~g})$ in a muffle furnace (Pyrolabo, France). Ash obtained was dissolved in $5 \mathrm{~mL}$ of $\mathrm{HCl} / \mathrm{HNO}$ and analyzed using the atomic absorption spectrophotometer (AAS model, SP9). The studied minerals were calcium (424.7 $\mathrm{nm})$, magnesium (285.2 nm), phosphorus (178.2 $\mathrm{nm})$, potassium (766.5 nm), sodium (589.6 $\mathrm{nm})$, iron $(248.3 \mathrm{~nm})$, and zinc $(213.9 \mathrm{~nm})$.

The amount of vitamin $\mathrm{C}$ in analyzed samples was determined by titration using the method described by Pongracz et al. (1971). About 10 $\mathrm{g}$ of ground fresh leaves were soaked into 40 $\mathrm{mL}$ metaphosphoric acid-acetic acid (2\%, $\mathrm{w} / \mathrm{v})$ for $10 \mathrm{~min}$. The mixture was centrifuged at $3000 \mathrm{rpm}$ for $20 \mathrm{~min}$ and the supernatant obtained was diluted and adjusted with $50 \mathrm{~mL}$ of bi-distilled water. Ten (10) $\mathrm{mL}$ of this mixture was titrated with dichlorophenolindophenol (DCPIP) $0.5 \mathrm{~g} / \mathrm{L}$.

\section{Polyphenolic compounds, tannins and flavonoids determination}

Polyphenols were extracted and determined by the method described by Singleton et al (1999) using Folin-Ciocalteu's reagent. A quantity $(1 \mathrm{~g})$ of lyophilized sample was soaked in $10 \mathrm{~mL}$ of methanol $70 \%$ (w/v) and centrifuged at $1000 \mathrm{rpm}$ for $10 \mathrm{~min}$. An aliquot $(1 \mathrm{~mL})$ of supernatant was oxidized with $1 \mathrm{~mL}$ of Folin-Ciocalteu's reagent and neutralized by $1 \mathrm{~mL}$ of $20 \%(\mathrm{w} / \mathrm{v})$ sodium carbonate. The reaction mixture was incubated for $30 \mathrm{~min}$ at ambient temperature and absorbance was measured at $745 \mathrm{~nm}$ by using a spectrophotometer (PG Instruments, England). The polyphenols content was obtained using a calibration curve of gallic acid $(1 \mathrm{mg} / \mathrm{mL})$ as standard.

Tannins of samples were quantified according to Bainbridge et al. (1996). In a test tube, 1 $\mathrm{mL}$ of the methanolic extract was mixed with $5 \mathrm{~mL}$ of vanillin reagent. The mixture was incubated in obscurity at ambient temperature for $30 \mathrm{~min}$. There after, the absorbance was read at $500 \mathrm{~nm}$ by using a spectrophotometer (PG Instruments, England). Tannins content of samples was estimated using a calibration curve of tannic acid $(2 \mathrm{mg} / \mathrm{mL})$ as standard.

The total flavonoids content was evaluated using the method reported by Meda et al. (2005). In a test tube, $0.5 \mathrm{~mL}$ of the methanolic extract was mixed with $0.5 \mathrm{~mL}$ 
methanol, $0.5 \mathrm{~mL}$ of aluminium chloride $(10 \%, \mathrm{w} / \mathrm{v}), 0.5 \mathrm{~mL}$ of potassium acetate $(1$ $\mathrm{M})$ and $2 \mathrm{~mL}$ of distilled water. The mixture was incubated in obscurity at ambient temperature for $30 \mathrm{~min}$. Then, the absorbance was measured at415 nm by using a spectrophotometer (PG Instruments, England). The total flavonoids were determined using a calibration curve of quercetin $(0.1 \mathrm{mg} / \mathrm{mL})$ as standard.

\section{Oxalates and phytates determination}

Oxalates content was performed using a titration method of Day and Underwood (1986). One (1) g of lyophilized sample was weighed into $100 \mathrm{~mL}$ conical flask. A quantity of $75 \mathrm{~mL}$ of sulphuric acid $(3 \mathrm{M})$ was added and stirred for $1 \mathrm{~h}$ with a magnetic stirrer. The mixture was filtered and $25 \mathrm{~mL}$ of the filtrate was titrated while hot against $\mathrm{KMnO}$ solution $(0.05 \mathrm{M})$ to the end point (persistent pink).

Phytates contents were determined using the Wade's reagent colorimetric method of Latta and Eskin (1980). A quantity (1 g) of lyophilized sample was mixed with $20 \mathrm{~mL}$ of hydrochloric acid $(0.65 \mathrm{~N})$ and stirred for $12 \mathrm{~h}$ with a magnetic. The mixture was centrifuged at $12000 \mathrm{rpm}$ for $40 \mathrm{~min}$. An aliquot $(0.5 \mathrm{~mL})$ of supernatant was added with $3 \mathrm{~mL}$ of Wade's reagent. The reaction mixture was incubated for $15 \mathrm{~min}$ and absorbance was measured at $490 \mathrm{~nm}$ by using a spectrophotometer (PG Instruments, England). Phytates content was estimated using a calibration curve of sodium phytate $(10 \mathrm{mg} / \mathrm{mL})$ as standard.

\section{Determination of molar ratio of antinutrients to minerals}

The molar ratio between antinutrient and mineral was obtained after dividing the mole of antinutrient with the mole of mineral
(Woldegiorgis et al., 2015). The mole of antinutrients and minerals was determined by dividing the weight of antinutrients and minerals with its atomic weight (phytate: 660 g/mol; Oxalate: 90 g/mol; Fe: 56 g/mol; Zn: $65 \mathrm{~g} / \mathrm{mol}$; Ca: $40 \mathrm{~g} / \mathrm{mol}$; mg: $24 \mathrm{~g} / \mathrm{mol}$ ).

\section{Cooking losses of nutrients}

The losses of nutrients during cooking were calculated using the following equation (1):

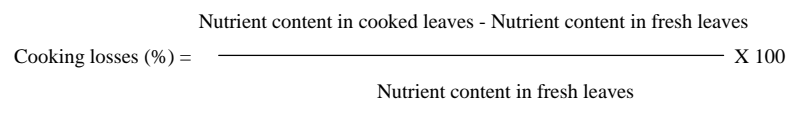

\section{Statistical Analysis}

All chemical analyses data were statistically analyzed by one-way analysis of variance (ANOVA). Means were compared by HSD test. The analyses were performed using the $\mathrm{R}$ statistical package ( $\mathrm{R}$ Development Core Team, 2011).

\section{Results and Discussion}

\section{Proximate composition}

The results of proximate composition of uncooked and cooked Justicia galeopsis leaves are shown in Table 1. The cooking had significant effect on the proximate composition of Justicia galeopsis leaves. The quantity of protein and ash in Justicia galeopsis leaves decreases with the increase in boiling time. High proteins and ash contents were observed in the leaves cooked during 30 minutes. Losses of protein and ash in Justicia galeopsis leaves were observed after 30 minutes of water cooking. These losses increase up to $14.20 \%$ for proteins and $36.18 \%$ for ashes. Lipid content increase with the increase in boiling time until it reached a maximum $(2.2 \%)$ for leaves cooked during 30 and $45 \mathrm{~min}$ and then decreased. The gain increases up to $12.25 \%$. The fiber and 
carbohydrate contents increase with the increase in boiling time. The lowest level of these nutrients was observed when the leaves are cooked during 30 minutes. For these nutrients, nutrients gain was observed.

\section{Minerals and Vitamin $\mathbf{C}$ determination}

The results of minerals and vitamin $\mathrm{C}$ composition of raw and cooked Justicia galeopsis leaves are shown in Table 2. Cooking had significant effect on the leaves of this plant.

When compared with the uncooked leaves, cooking resulted in significant decrease in phosphorus (11.88 to $26.02 \%$ ), potassium (5.84 to $11.05 \%$ ), magnesium (14.75 to 32.13 $\%)$, sodium (6.21 to $18.35 \%$ ) and vitamin C (94.75 to $96.84 \%)$.The losses in these micronutrients increase with the increase in boiling time. But the lowest loss percentages $(11.88 \%$ for phosphorus, $5.84 \%$ for potassium, $14.75 \%$ for magnesium, $6.21 \%$ for sodium and -94.75 for vitamin C) were observed when the leaves were cooked during 30 minutes.

Compared to fresh leaves, a significant increase had been observed in the calcium (32.84\%), iron $(0.84 \%)$ and zinc $(6.87 \%)$ content when Justicia galeopsis leaves were cooked during 30 minutes. Thus, the highest content of these minerals was revealed after 30 minutes of cooking $(30.66 \mathrm{~g} / \mathrm{kg}$ of calcium, $458.98 \mathrm{mg} / \mathrm{kg}$ of iron, and $160.33 \mathrm{mg} / \mathrm{kg}$ of zinc). However, these contents decreased after 45 and 60 minutes of water cooking.

\section{Polyphenolic compounds, tannins and flavonoids}

Results obtained from the determination of polyphenolic compounds, tannins and flavonoïds content in Justicia galeopsis leaves showed that cooking decreased significantly these compounds (Table 3).

Fresh leaves polyphenolic compounds (83.00 mg EAG/100 g), tannins (16.57 mg EG/100 g) and flavonoids (66.33 mg EC/100 g) were higher than those of cooked leaves. Among the cooked leaves, those cooked during 30 minutes contained the highest amounts of polyphenolic compounds (79.91 mg EAG/100 $\mathrm{g})$, flavonoids (13.39 $\mathrm{mg} \mathrm{EG} / 100 \mathrm{~g}$ ) and tannins (54.44 mg EC/100 g).

The loss percentages increase up to $42.24 \%$ for polyphenolic compounds, $62.70 \mathrm{mg} \%$ for flavonoids and $58.65 \%$ for tannins when the leaves are cooked during 60 minutes.

\section{Oxalates and phytates determination}

Results of antinutrient factors contents of Justicia galeopsis uncooked and cooked leaves are indicated in Table 4. These results had showed that cooking time significantly decrease oxalates and phytates levels in Justicia galeopsis leaves. The uncooked leaves and the leaves cooked during 30 minutes were presented the highest amount of oxalates (740.67 and $667.33 \mathrm{mg} / 100 \mathrm{~g}$ ) and phytates (33.83 and $29.83 \mathrm{mg} / 100 \mathrm{~g}$ ). The loss percentages increase up to $45.55 \%$ for oxalates, and $33.55 \%$ for phytates when the leaves are cooked during 60 minutes.

\section{Molar ratio of antinutrients to minerals}

The molar ratios between antinutrients and minerals of uncooked and cooked Justicia galeopsis leaves were showed in Table 5. The results indicated that molar ratio of [Phytate]/[Fe] (0.04 to 0.06), [Phytate]/[Zn] (0.17 to 0.22$)$, [Phytate]/[Ca] (0.0 to 0.0$)$, [Ca][Phytate]/[Zn] (0.08-0.14), [Oxalate]/[Ca] (0.09 to 0.14$)$ and [Oxalate]/[(Ca $+\mathrm{Mg})]$ (0.11 to 0.18 ) for $J$. galeopsis leaves were low compared with their corresponding critical value. 
Table.1 Proximate composition of uncooked and cooked Justicia galeopsis leave

\begin{tabular}{|l|c|c|c|c|}
\hline Parameters & \multicolumn{4}{|c|}{ Cooking times } \\
\hline Protein (\%) & $\mathbf{C T}_{\mathbf{0}}$ & $\mathbf{C T}_{\mathbf{3 0}}$ & $\mathbf{C T}_{\mathbf{4 5}}$ & $\mathbf{C T}_{\mathbf{6 0}}$ \\
\hline Loss after cooking(\%) & $14.08 \pm 0.52 \mathbf{a}$ & $13.33 \pm 0.29 \mathbf{a b}$ & $12.75 \pm 0.00 \mathbf{b c}$ & $12.08 \pm 0.14 \mathbf{c}$ \\
\hline Lipid (\%) & & $-5,33$ & -9.45 & -14.20 \\
\hline Loss after cooking(\%) & $2.00 \pm 0.04 \mathbf{b}$ & $2.24 \pm 0.10 \mathbf{a}$ & $2.25 \pm 0.00 \mathbf{a}$ & $2.00 \pm 0.01 \mathbf{b}$ \\
\hline Ash (\%) & & 12 & 12.5 & 0 \\
\hline Loss after cooking(\%) & $15.67 \pm 1.15 \mathbf{a}$ & $12.33 \pm 0.58 \mathbf{b}$ & $10.00 \pm 0.00 \mathbf{c}$ & $10.00 \pm 0.00 \mathbf{c}$ \\
\hline Carbohydrate (\%) & $68.25 \pm 0.64 \mathbf{c}$ & -21.31 & -36.18 & -36.18 \\
\hline Loss after cooking(\%) & & $5.09 \pm 0.5 \mathbf{b}$ & $75.00 \pm 0.00 \mathbf{a}$ & $75.92 \pm 0.14 \mathbf{a}$ \\
\hline Fibers (\%) & $30.00 \pm 0.86 \mathbf{d}$ & $33.83 \pm 0.29 \mathbf{c}$ & $38.67 \pm 0.29 \mathbf{b}$ & $43.33 \pm 1.04 \mathbf{a}$ \\
\hline Loss after cooking(\%) & & 12.77 & 28.90 & 44.43 \\
\hline
\end{tabular}

Data are represented as means \pm SD $(n=3)$. Different letters within the same line indicate significant differences among cooking times $(\mathrm{P}<0.05)$

Table.2 Minerals and vitamin composition of uncooked and cooked Justicia galeopsis leaves

\begin{tabular}{|c|c|c|c|c|}
\hline \multirow[t]{2}{*}{ Parameters } & \multicolumn{4}{|c|}{ Cooking times } \\
\hline & $\mathrm{LC}_{0}$ & $\mathbf{L C}_{30}$ & $\mathrm{LC}_{45}$ & $\mathrm{LC}_{60}$ \\
\hline Phosphorus (g/kg) & $19.10 \pm 0.00 \mathbf{a}$ & $16.83 \pm 0.06 \mathbf{b}$ & $16.13 \pm 0.11 \mathbf{c}$ & $14.13 \pm 0.06 \mathbf{d}$ \\
\hline Loss after cooking (\%) & & -11.88 & -15.55 & -26.02 \\
\hline Potassium $(\mathrm{g} / \mathrm{kg})$ & $334.28 \pm 7.04 \mathbf{a}$ & $\begin{array}{c}314.75 \pm \\
1.01 \mathbf{b}\end{array}$ & $304.41 \pm 0.36 \mathbf{c}$ & $297.33 \pm 1.93 \mathbf{c}$ \\
\hline Loss after cooking (\%) & & -5.84 & -8.94 & -11.05 \\
\hline Calcium (g/kg) & $23.08 \pm 0.08 \mathbf{b}$ & $30.66 \pm 0.01 \mathbf{a}$ & $22.22 \pm 0.01 \mathbf{c}$ & $20.22 \pm 0.02 d$ \\
\hline Loss after cooking (\%) & & 32.84 & -3.73 & -12.39 \\
\hline Magnesium (g/kg) & $6.10 \pm 0.03 \mathbf{a}$ & $5.20 \pm 0.05 \mathbf{b}$ & $4.14 \pm 0.03 \mathbf{c}$ & $4.27 \pm 0.08 \mathbf{c}$ \\
\hline Loss after cooking (\%) & & -14.75 & -32.13 & -30.00 \\
\hline Iron $(\mathbf{m g} / \mathbf{k g})$ & $455.17 \pm 0.01 \mathbf{b}$ & $\begin{array}{c}458.98 \pm \\
0.01 \mathrm{a}\end{array}$ & $453.93 \pm 0.01 c$ & $453.63 \pm 0.01 d$ \\
\hline Loss after cooking (\%) & & 0.84 & -0.27 & -0.34 \\
\hline Zinc $(\mathbf{m g} / \mathbf{k g})$ & $150.02 \pm 0.09 b$ & $\begin{array}{c}160.33 \pm \\
0.04 a\end{array}$ & $135.41 \pm 0.05 \mathbf{b}$ & $132.23 \pm 0.01 \mathbf{b}$ \\
\hline Loss after cooking (\%) & & 6.87 & -9.74 & -11.86 \\
\hline Sodium (mg/kg) & $11.28 \pm 0.01 \mathbf{a}$ & $10.58 \pm 0.01 \mathbf{b}$ & $9.36 \pm 0.01 \mathbf{c}$ & $9.21 \pm 0.01 \mathrm{~d}$ \\
\hline Loss after cooking (\%) & & -6.21 & -17.02 & -18.35 \\
\hline Vitamin C (mg/100g) & $90.47 \pm 0.54 \mathbf{a}$ & $4.75 \pm 1.60 \mathrm{~b}$ & $3.80 \pm 1.62 \mathrm{~b}$ & $2.86 \pm 0.03 \mathbf{b}$ \\
\hline Loss after cooking (\%) & & -94.75 & -95.80 & -96.84 \\
\hline
\end{tabular}


Table.3 Antioxydants composition of uncooked and cooked Justicia galeopsis leaves

\begin{tabular}{|l|l|l|l|l|}
\hline \multirow{2}{*}{ Parameters } & \multicolumn{4}{|c|}{ Cooking times } \\
\cline { 2 - 5 } & \multicolumn{1}{|c|}{$\mathbf{L C}_{\mathbf{0}}$} & \multicolumn{1}{|c|}{$\mathbf{L C}_{\mathbf{3 0}}$} & \multicolumn{1}{c|}{$\mathbf{L C}_{\mathbf{4 5}}$} & \multicolumn{1}{c|}{$\mathbf{L C}_{\mathbf{6 0}}$} \\
\hline Polyphenols (mg EAG/100 g) & $83.00 \pm 2.29 \mathbf{a}$ & $79.91 \pm 0.52 \mathbf{a}$ & $64.48 \pm 0.00 \mathbf{b}$ & $47.94 \pm 0.29 \mathbf{c}$ \\
\hline Loss after cooking (\%) & & -3.72 & -22.31 & -42.24 \\
\hline Flavonoids (mg EQ/100 g) & $16.57 \pm 0.80 \mathbf{a}$ & $13.39 \pm 0.25 \mathbf{b}$ & $8.46 \pm 0.32 \mathbf{c}$ & $6.18 \pm 0.32 \mathbf{c}$ \\
\hline Loss after cooking (\%) & & -19.19 & -48.94 & -62.70 \\
\hline Tannins (mg EC/100 g) & $66.33 \pm 2.31 \mathbf{a}$ & $54.44 \pm 2.41 \mathbf{b}$ & $41.55 \pm 0.35 \mathbf{c}$ & $27.43 \pm 2.31 \mathbf{d}$ \\
\hline Loss after cooking (\%) & & -17.93 & -37.36 & -58.65 \\
\hline
\end{tabular}

Data are represented as means \pm SD $(n=3)$. Different letters within the same line indicate significant differences among cooking times $(\mathrm{P}<0.05)$

Table.4 Antinutrients composition of uncooked and cooked Justicia galeopsis leaves

\begin{tabular}{|l|c|c|c|c|}
\hline \multirow{2}{*}{ Parameters } & \multicolumn{4}{|c|}{ Cooking times } \\
\cline { 2 - 5 } & \multicolumn{1}{|c|}{$\mathbf{L C}_{\mathbf{0}}$} & \multicolumn{1}{c|}{$\mathbf{L C}_{\mathbf{3 0}}$} & \multicolumn{1}{c|}{$\mathbf{L C}_{\mathbf{4 5}}$} & \multicolumn{1}{c|}{$\mathbf{L C}_{\mathbf{6 0}}$} \\
\hline Oxalates (mg/100 g) & $740.67 \pm 12.70 \mathbf{a}$ & $667.33 \pm 12.70 \mathbf{b}$ & $440.00 \pm 0.00 \mathbf{c}$ & $403.33 \pm 12.70 \mathbf{d}$ \\
\hline Loss after cooking (\%) & & -9.90 & -40.59 & -45.55 \\
\hline Phytates (mg/100 g) & $33.83 \pm 2.45 \mathbf{a}$ & $29.83 \pm 0.35 \mathbf{b}$ & $26.07 \pm 0.77 \mathbf{c}$ & $22.48 \pm 0.63 \mathbf{d}$ \\
\hline Loss after cooking(\%) & & -11.82 & -22.94 & -33.55 \\
\hline
\end{tabular}

Data are represented as means \pm SD $(n=3)$. Different letters within the same line indicate significant differences among cooking times $(\mathrm{P}<0.05)$

Table.5 Molar ratio between phytate and minerals, oxalate and minerals

\begin{tabular}{|l|c|c|c|c|c|}
\hline \multirow{2}{*}{ Parameters } & \multicolumn{4}{|c|}{ Cooking times } & \multirow{2}{*}{ Critical level } \\
\cline { 2 - 5 } & LC $_{\mathbf{0}}$ & LC $_{\mathbf{3 0}}$ & $\mathbf{L C}_{\mathbf{4 5}}$ & $\mathbf{L C}_{\mathbf{6 0}}$ & \\
\hline Antinutrient/mineral ratio & & & & & \\
\hline [Phytate]/[Fe] & 0.06 & 0.06 & 0.05 & 0.04 & 0.4 \\
\hline$[$ Phytate]/[Zn] & 0.22 & 0.18 & 0.19 & 0.17 & $<1.5$ \\
\hline$[$ Phytate]/[Ca & 0.00 & 0.00 & 0.00 & 0.00 & 0.5 \\
\hline [Ca][Phytate]/[Zn & 0.13 & 0.14 & 0.11 & 0.08 & $<0.5$ \\
\hline [Oxalate]/[Ca] & 0.14 & 0.10 & 0.09 & 0.09 & 2.5 \\
\hline [Oxalate]/[(Ca+ Mg)] & 0.18 & 0.13 & 0.11 & 0.12 & 2.5 \\
\hline
\end{tabular}

Fe: iron; Zn: Zinc, Ca: calcium; Mg: magnesium

The quantity of protein and ash in Justicia galeopsis leaves had decrease with the increase in boiling time with high proteins and ashes contents in the leaves cooked during 30 minutes. Comparatively, $J$. galeopsis leaves cooked during 30, 45 and 60 min had a higher protein and ash content than the sweet potato $(1.9$ and $0.6 \%)$, spinach
Ceylon (1.6 and $1.5 \%)$ edible hibiscus $(3.4$ and $1.1 \%$ ) and cassava (3.9 and $1.1 \%$ ) cooked leaves (WHO, 2004). This makes the leaves of this plant a good source of protein, essential for the synthesis of body tissues and regulatory substances such as enzymes and hormones (Vaughan and Judd, 2003). 
Lipid content of cooked leaves had reached a maximum of $2.2 \%$. This content was higher when compared to those cited by WHO (2004) such as the sweet potato leaves (0.7 $\%)$, spinach Ceylon (0.1\%), edible hibiscus $(0.8 \%)$ and cassava leaves $(1.1 \%)$. The fat in this plant are far better than those mentioned in animal fat such as lard, butter and beef fat (Estelle and Karen, 1999).A diet including $J$. galeopsis should be more palatable than that of green leafy vegetables mentioned above because dietary fats enhance palatability by absorbing and retaining flavors and by influencing the texture of foods (Press, 1985).

The crude fiber content of cooked J. galeopsis leaves was higher than that of sweet potato leaves (3\%), spinach Ceylon $(3.7 \%)$ and cassava leaves $(4.6 \%)$. This makes it a more favorable vegetable since high fiber contents in foods help in digestion, prevention of colon cancer (UICC/WHO, 2005) and in the treatment of diseases such as obesity, diabetes and gastrointestinal disorders.

Phosphorus, potassium, magnesium, sodium, vitamin $\mathrm{C}$ contents had decreased after $30 \mathrm{~min}$ of cooking while those of calcium, iron and zinc increase then decrease after $45 \mathrm{~min}$ of cooking. The high level of these minerals was observed in leaves cooked during $30 \mathrm{~min}$.

Mineral losses during J. galeopsis leaves cooking could be caused by oxidation of water-soluble mineral and thermal destruction but not leaching as mentioned in Oulai et al., (2014) study on some leafy vegetables. Indeed, cooking water in this study was not discharged after cooking.

The remaining quantity of these nutrients in $J$. galeopsis leaves was higher than those of sweet potato leaves (potassium $(98 \mathrm{mg} / 100$ g), magnesium (22 mg/100 g), sodium (7 mg $/ 100 \mathrm{~g})$, vitamin C (3 mg/100 g), calcium (125 $\mathrm{mg} / 100 \mathrm{~g})$, iron $(1.2 \mathrm{mg} / 100 \mathrm{~g})$ and zinc $(0.1$ $\mathrm{mg} / 100 \mathrm{~g})$ ) indicated by WHO (2004). Considering, the recommended dietary allowance for minerals (WHO, 2004): calcium (1000 mg/day), phosphorus (800 $\mathrm{mg} /$ day), magnesium (400 mg/day), iron (8 $\mathrm{mg}$ /day) and zinc (6 $\mathrm{mg} /$ day), the consumption of $46 \mathrm{~g}$ of $J$. galeopsis leaves cooked during $30 \mathrm{~min}$ could cover at least $50 \%$ of nutritional intake in calcium, phosphorus, magnesium, iron and zinc.

The polyphenol, flavonoid and tannin contents of J. galeopsis leaves decreased with increasing cooking time with high level in the leaves cooked during $30 \mathrm{~min}$. The decrease in tannins, polyphenols and flavonoids during cooking is due to thermal degradation. Contrasting results were found in the levels of polyphenols and flavonoids in white caya (Cleome gynandra) leaves (Moyo et al., 2016). The percent gain in the total phenols contents during cooking may be due to there lease of phenolic compounds trapped in the fibers of leafy vegetables.

The oxalate and phytate contents decrease with increasing cooking time. These results are identical to those of Oulai et al., (2014) in the Hibiscus sabdariffa leaves. The reduction of the levels of oxalates and phytates in these leafy vegetables is due to their thermosensitivity. Cooking is advantageous and appears as a detoxification procedure by removing these anti-nutritional factors and improving the health status of consumers (Ekopand Eddy, 2005). Indeed, oxalates and phytates are anti-nutrients which chelate divalent cations such as calcium, magnesium, zinc and iron, thereby reducing their bioavailability (Sandberg, 2002). The oxalate and phytate contents of cooked Justicia galeopsis leaves are higher than those found in cooked Hibiscus sabdariffa leaves. This result is due to the cooking water of Justicia galeopsis leaves which was not discard in contrary to $H$. sabdariffa cooking water which 
fresh leaves contained more oxalates and phytates. However, the level of oxalate in $J$. galeopsis leaves is not major concern for a normal healthy person, as about 298-335 g of cooked leaves during 30 min would needs to be consumed to acquire $2-5 \mathrm{~g}$ of oxalate, which is thought to be toxic level for humans (Hassan and Umar, 2004).But also, it takes only an average of $46 \mathrm{~g}$ of cooked leaves to made $J$. galeopsis sauce for a normal person of $65 \mathrm{~kg}$.

From the result, it was observed that in $J$. galeopsis,[oxalate]/[Ca] ratio (0.09 to 0.14$)$, [oxalate $] /[(\mathrm{Ca}+\mathrm{Mg})]$ ratio $(0.11$ to 0.18$)$, [phytates]/[Ca] ratios $(0.00)$, [phytates $] /[\mathrm{Fe}]$ ratios $(0.04$ to 0.06$)$ and [phytates]/[Mg] ratios $(0.17$ to 0.22$)$ are below the critical level known to impair divalent minerals bioavailability (Umar et al., 2007). The present of oxalate and phytate in J. galeopsis leaves don't affect $t$ he bioavailability of calcium, iron, magnesium and zinc.

In conclusion this study had evaluated the effect of cooking on the biochemical, phytochemical and mineral composition of Justicia galeopsis edible leaves. The results showed that a prolonged cooking time decreased significantly the content of nutrients such as proteins, ashes, vitamin $\mathrm{C}$ and antioxidant components. Therefore, the optimal cooking time for J. galeopsis leaves would be $30 \mathrm{~min}$. Indeed, the content of vitamins $\mathrm{C}$, polyphenolic compounds, tannins, flavonoids are acceptable. In addition, the iron, calcium, zinc and magnesium contents in the cooked leaves presented a high bioavailability. It should be noted that the anti-nutrient (phytates and oxalates) contents after this cooking time remain within the physiologically tolerable limit.

In the final, the cooked leaves of J. galeopsis contain a good quantity of nutrients which could help to cover the deficit of nutrients of the populations. Also, its high iron content could be beneficial for anemic patients.

\section{Acknowledgements}

The authors thank technician of the national floristic center Mr. Yapo ASSI Jean for authentication and identification of Justicia galeopsis leaf and Hanzi Kerene KOUAME for its assistance in samples lyophilization.

\section{References}

Agbemafle, R., E. A. Obodai, G. E. Adukpo and Amprako, D. N. 2012. Effects of boiling time on the concentrations of vitamin $\mathrm{c}$ and beta-carotene in five selected green vegetables consumed in Ghana. Advances in Applied Science Research, 3(5): 2815-2820.

Aka, N., S. B. Bamba, G. Soro and Soro, N. 2013. Etude hydrochimique et microbiologique desnappes d'altérites sous climat tropical humide: cas du département d'Abengourou (Sud-Est de la Côte d'Ivoire). Larhyss Journal, 16: 31-52.

AOAC. 1990. Official methods of analysis of the Association of Official Analytical Chemists. 15th Ed, Association of Official Analytical Chemists.

Bainbridge, Z., K. Tomlins, K. Willings and Westby, A. 1996. Part 4 advanced methods.Natural resources institute, 1: 43-79.

Bernfeld, P. 1955. Amylase $\alpha$ and $\beta$,In I. S. P. Colowich and N.O. Kaplan (Eds.), 9th Ed, Method in enzymology, New York: Academic Inc, pp. 149-158.

Causeret, J. 1986. Caractéristiques nutritionnelles et bon usage de nos aliments. In: L'alimentation humaine. Evolution et tendances, INRA.

CNRA. 2011. Socio-economical importance of leafy vegetables for the urban populations of Côte d'Ivoire, CNRA. 
Day, R. A. and Underwood, A. L. 1956. Quantitative Analysis, 5th Ed., Prentice Hall Publication, Upper Saddle River.

Dubois, M. K., Gilles, J. Hamilton, P. Rebers and Smith F. 1986. Colorimetric methods for determination of sugars and related substances. Analytical chemistry, 28:350-356.

Ekop, A. S. and Eddy, N.O. 2005. Comparative Studies of the level of toxicants in the seed of Indian almond (Terminalia catappa) and African walnut (Coula edulis). ChemClass Journal, 2: 74-76.

Estelle L. and Karen, M. 1999. Plants and Society, 2nd Ed. The McGraw-Hill Companies, Inc.

FAO. Revue critique des méthodes d'analyses. Food and Agriculture Organization, 1998.

Gupta, K. and Wagle, D. S. 1988. Nutritional and antinutritional factors of green leafy vegetables. Journal of Agricultural and Food Chemistry, 36: 472-474.

Gupta, S. and Bains, K. 2006. Traditional cooked vegetable dishes as important sources of ascorbic acid and b -carotene in the diets of Indian urban and rural families. Food Nutrition Bulletin, 27: 306-310.

Hassan, L. G. and Umar, K. J. 2004. Antinutritive factors in African locust beans (Parkiabiglobosa). Proceedings of $27^{\text {th }}$ International Conference of Chemical Society of Nigeria, pp. 322326.

Kubmarawa, D., I. F. Andenyang and Magomya, A.M. 2009. Proximate composition and amino acid profile of two nonconventional leafy vegetables (Hibiscus cannabinus and Haematostaphis barteri). African Journal of Food Science, 3: 233-236.

Loukou, A. L., K. Y. B. Anvoh, K. H. Kouakou and Brou, K. 2018. Nutritional composition and bioavailability prediction calcium, iron, zinc and magnesium in Justicia galeopsis leaves in Côte d'Ivoire. International Journal of Biological and Chemical Sciences, 12 (6):2615-2625.

Meda, A.,C. E. Lamien, M. Romito, J. Millogo and Nacoulma, O. G. 2005. Determination of the total phenolic, flavonoid and proline contents in Burkina Fasan honey, as well as their radical scavenging activity. Food Chemistry, 91:571-577.

Moyo, S. M., E. Kayitesi, V. Mavumengwana and Madala, N. E. 2016. Effects of cooking and drying on the total phenolic, total flavonoid content, antioxidant and antibacterial activity of Cleome gynandra (Spider plant)," International Conference on Advances in Science, Engineering, Technology and Natural Resources (ICASETNR16). pp. 24-25.

Latta, M. and Eskin,M. 1980. A Simple and Rapid Colorimetric Method for Phytate Determination. Journal of Agricultural and Food Chemistry, 28: 1313-1315.

Leskova, E., J. Kobıkova, E. Kovacikova, M. Kosicka, J. Porubska and Holc1kova, K. 2006. Vitamin losses: retention during heat treatment and continual changes expressed by mathematical models. Journal of Food Composition and Analysis, 19: 252-276.

Oulai, D. P., T. L. Zoue, E. M. Bedikou, R.M. Megnanou and Niamke, L. S. 2014. Impact of cooking on nutritive and anti oxidant caracteristics of leafy vegetables consumed in northern Côte d'Ivoire. International Journal of Plant Animal and Environmental Sciences, 4 (3):576-585.

Pongracz, G., H. Weiser and Matzinger, D. 1971. Tocopherols-Antioxydant. Fat Science Technology, 7: 90-104.

Press, F. "Postponement of the 10th edition of the RDAs. 1985. Journal of the 
American Dietetic Association, 85: 1644-1645.

Randrianatoandro, V. A. 2010. Identification et caractérisation des plats sources en micronutriments consommés en milieu urbain (Manjakaray, Madagascar): étude des plats à base de légumesfeuilles. Thèse, Universitéd' Antananarivo, Madagascar.

R Development Core Team. 2011. R: A language and environment for statistical computing. The $\mathrm{R}$ foundation for statistical computing Vienna, Austria.

Salkeld, R. M., 1991. Bêta-Carotène et prévention du cancer.Cahiers de Nutrition et de Diététique, 26 (1): 61 64.

Sandberg, A. S. 2002. Bioavailability of minerals in legumes. British Journal of Nutrition, 88(S3): S281-S285.

Singleton, V. L., R. Orthofer and LamuelaRaventos, R. M. 1999. Analysis of total phenols and other oxidation substrates and antioxidants by means of FolinCiocalteu reagent. Methods Enzymology, 299: 152-178.

UICC/WHO. 2005. Global Action Against Cancer NOW, UICC and WHO Publications Department.
Umar, K. J., L. G. Hassan, S. M. Dangoggo, M. Inuwa and Amustapha, M. N. 2007. Nutritional content of Melochiacor chorifolia (Linn.) leaves. International Journal of Biological and Chemical, 1: 250-255.

Vaughan, J. G. and Judd, P. A. 2003. The Oxford Book of Health Foods: A Comprehensive Guide to Natural Remedies. 1st Ed. Oxford University Press.

WHO. 2004. Human vitamin and mineral requirements, 2 ndEd, WHO.

Woldegiorgis, A. Z., D. Abate, G. D. Haki and Ziegler, G. R. 2015. Major, minor and toxic minerals and anti-nutrients composition in edible mushrooms collected from Ethiopia. Journal of Food Processing and Technology, 6(3):430-437.

Wolf,J. P. 1968. Manuel d'analyse des corps gras. Azoulayéd., Paris.

Yao, K., M. W. Koné, B. Bonfoh and Kamanzi, K. 2014. Antioxidant activity and total phenolic content of nine plants from Côte d'Ivoire (West Africa). Journal of Applied Pharmaceutical Science,4(8): 036-041.

\section{How to cite this article:}

Ahou Leticia Loukou, Raissa Sandy Assi, Koutoua Yves Blanchard Anvoh, Kouakou Brou and Louise Atchibri-Anin. 2020. Impact of Water Cooking on Nutritive Characteristics of Justicia galeopsis Leaves Consumed in Côte d'Ivoire. Int.J.Curr.Microbiol.App.Sci. 9(10): 1969-1979. doi: https://doi.org/10.20546/ijcmas.2020.910.240 